\title{
Making Citizens, Banishing Immigrants: The Discipline of Deportation Investigations, $1908-1913$
}

\section{Fiona Alice Miller}

In the fall of 1908, the sad case of a new immigrant family was brought to the attention of the Superintendent of Immigration in Ottawa. An Ontario Inspector of Asylums, Prisons and Public Charities reported that a young Toronto woman, who was clearly an "imbecile," was living in an unheated shack with her infant. Her husband was a "worthless cripple," slovenly and "resistant to employment"; he had virtually abandoned her and she was now dependent on the charity of neighbours and local churches. Arguing that these people should never have been permitted to land in Canada as immigrants, and fearing that all three would soon be charges on the public purse, the Inspector began making arrangements with Ottawa for their speedy deportation. ${ }^{1}$

At first glance, the story of the couple we shall call John and Edith Dorset demonstrates the importance of deportation in, as Barbara Roberts has eloquently put it, "reliev[ing] employers, municipalities, and the state from the burdens of poverty, unemployment and political unrest." 2 Yet closer examination calls this conclusion into question. For though the Dorsets' deportation was ordered, it was not put into effect. Instead, the couple were the subjects of repeated investigations, and though deemed technically deportable, were allowed to stay.

When the immigration inspector arrived to escort Edith and her child in December 1908, John refused to accompany them, or even permit their removal. He insisted that he was the owner of property, and was earning his own living. The Superintendent of Immigration in Ottawa was unimpressed by John's limited bread-winning abilities, ${ }^{3}$ and his concern was confirmed by the local police who asserted that these were not, and never would be, desirable citizens. But the Superintendent agreed to waive the deportation for a short period when John gained the support of a local church Minister and his employer. "Should he fail to make good," he noted, "proceedings can be revived."

It soon appeared that this would be necessary. In the summer of 1909 , an article appeared in a local newspaper with the headline, "Mothers Neglect their Children: Sad Cases of Insanity Reported to Police" which reported that Edith Dorset had been held at the police station with her eight month old child. Edith believed she had been instructed by God not to feed her baby. The article resulted in a renewed investigation and the Toronto police were requested to look into the situation again. This time the report was favourable. A staff sergeant wrote that though the wife suffered from "queer spells," brought on 
by "milk fever," the husband was employed and was paying in instalments for property he owned. This was not a case for interference, he concluded.

The limited historiography concerning deportation suggests its primary importance as an instrument for expelling undesirables. Donald Avery's Dangerous Foreigners laid the groundwork for our understanding of immigration policy in Canada and produced a parallel interpretation of deportation. Avery argued that the official federal policy of encouraging the immigration of agricultural settlers obscured an unofficial policy of building an industrial proletariat through the immigration of waged labourers. For Avery, the role of deportation was a logical corollary: it served to rid Canada of troublesome elements, primarily labour radicals. ${ }^{4}$

Avery's analysis of deportation was adopted and expanded upon by Barbara Roberts. In her groundbreaking book, Whence They Came: Deportation from Canada, 1900-1935, Roberts argued that Canada's deportation system functioned as a "purely administrative proceeding." It could be prosecuted in variable ways to serve the needs of the immediate situation: if immigrant radicals seemed to be fostering working class protest in 1919, deportation could be used to remove the troublemakers; when economic recessions or the Great Depression threatened immigrant radicalism and placed workers on relief, deportation could serve the dual purpose of reducing both costs and unrest. Deportation therefore served the interests of the state, which itself served the interests of Canadian capital. "When the companies laid off immigrant workers," Roberts wrote, "or accident or other misfortune struck them, the deportation system took care of the problem. The immigrant unemployed and unfit became visible, were identified, and whenever possible, were deported."5

Arguing against the narrative of immigrant failure which placed responsibility for deportation on the shoulders of individual immigrants, Roberts exposed a consistent pattern of deportations for economic, political and moral reasons. Her book outlined the development of a federal bureaucracy, and its supportive legal framework, which presided over an active system of investigation and expulsion. In the early years, as the system was developing, both formal and extralegal methods of deportation were in use. As the bureaucracy matured, particularly after World War I, deportation procedures became more carefully defined. But throughout the period Roberts reviews, the legal framework served an administrative imperative to rid the country of the unwanted. "The Department [of Immigration]," Roberts wrote, "considered itself responsible for the protection of the public purse, the public health, and the public morals." 6

In her work on deportation, Roberts focused on official rhetoric (both public and private) and praxis, and attended primarily to the development and use of an infrastructure of expulsion. In this article, I use the case files of Ontario's developing deportation bureaucracy to build on Roberts' analysis. 
My study uses data from a convenience sample of fifty-one deportation case files from Ontario, in the five years before the First World War. ${ }^{7}$ This source highlights the importance of the process of deportation investigation, where expulsion was not the necessary outcome. The power of deportation, I argue, was manifested in more than its execution. The administrative flexibility of deportation, which Roberts so carefully documented, allowed decisions to be made on the basis of normative standards of immigrant conduct, particularly gendered standards. The process of investigation, and the threat of deportation, were elements in a system which encouraged conformity with such standards. Without denying the coercive intent of the deportation infrastructure, my review of case files from the Ontario deportation bureaucracy suggests that the story of the Dorsets is more typical of Canada's deportation history than the story of expulsion. Far more immigrants were investigated for deportation than were actually deported: between the years of 1908 and 1913, for which Ontario deportation case files are extant, the Ontario deportation bureaucracy investigated some 8,000 persons; of these, only 1,300 immigrants were finally expelled. ${ }^{8}$ Through deportation investigations, state actors of many kinds, other regulatory authorities (particularly physicians), and sometimes immigrants and their allies, played a role in re-shaping individual immigrants and immigrant families. Deportation was a system of moral regulation which made citizens at least as often as it banished immigrants. ${ }^{9}$

\section{THE DEPORTATION SYSTEM}

The federal government established the standards for admission of immigrants to Canada through the provisions of the Immigration Act; the federal government also provided systems of medical inspection, detention and expulsion to screen potential immigrants and cure or remove the incapacitated and indigent. The first federal controls on immigration were legislated in 1869 and revised in $1872 .^{10}$ The 1872 Act was particularly concerned to limit the spread of contagious diseases and to restrict the admission to Canada of persons likely to become a public charge. It therefore established quarantine stations and required the medical superintendent to prohibit the entry of "any lunatic, idiotic, deaf and dumb, blind or infirm person not belonging to any immigrant family," and permitted impoverished immigrants to be turned back. ${ }^{11}$ This nineteenth-century Act did not encode fears of the medically unfit immigrant as such; its concern was, on the one hand, the spread of contagious disease and, on the other, the threat of indigence where the sick individual was not embedded in and supported by a family.

This legislative perspective changed in the twentieth century with the active lobbying efforts of Canada's medical professionals. ${ }^{12}$ The 1902 Act permitted the prohibition of an individual afflicted with "a loathsome, dangerous or infectious disease or malady,"13 and the trend toward the medicalization and individualisation of the unfit immigrant was intensified by 
the 1906 Act which established fixed categories of the excluded: the feebleminded, idiot, epileptic, insane, pauper, afflicted and immoral. ${ }^{14}$

In addition to instituting clear categories of restricted immigrants, the 1906 Act legalised the existing de facto system of deportation. Coming into force in July of that year, it permitted the deportation of an immigrant who had resided in Canada for less than two years and who had "become a charge upon the public funds, whether municipal, provincial, or federal, or an inmate of or a charge upon any charitable institution." In 1910, the Act was expanded to permit "deportation on the grounds of moral or political unsuitability" and the residence period during which deportation was allowed was extended to three years. ${ }^{15}$ These legislative changes responded to shifts in the size and scope of immigration into Canada. The turn of the twentieth century witnessed a massive influx of migrants, approximately two-and-a-half million between 1896 and 1914. While the majority of these immigrants were Englishspeaking, a substantial proportion were from continental Europe, fostering the ethnic diversification of Canada's population, and provoking racist anxieties. ${ }^{16}$ Such concerns were exacerbated by eugenic theories which suggested that the defectiveness of individual immigrants was hereditary, and would persist in, and threaten, future generations. ${ }^{17}$

The federal immigration legislation provided the framework within which the provincial and municipal governments manoeuvred as they sought to deal with "unfit" immigrants within their jurisdictions. In Ontario, there had been a near continuous stream of departments, bureaux and branches of existing ministries which dealt with immigration. Before the First World War, the responsible service was the Bureau of Colonization within, first, the Department of Lands and Mines, and then, the Department of Agriculture. The official provincial policy, like the official federal policy, was to "facilitate and direct land settlement in those parts of the Province that were being surveyed into townships, and otherwise prepared for agricultural settlement."18 Official policy did not foreclose on the possibility of "failure" among these immigrants. It was acknowledged that some immigrants would not succeed in their adopted homes. In general, however, reports from the Bureau reassured readers that the quality of immigrants was continuously improving through the better marketing of Ontario's virtues and the better inspection of potential recruits by Ontario government agents or federal medical inspectors.

While conceding their existence, then, Ontario's Bureau of Colonization did not deal with immigrant "failures." Yet the involvement of the province was essential for the identification of immigrants who had made it past the ports of entry. It was in the provincially directed and inspected hospitals, asylums, reformatories, gaols, prisons, and charitable institutions that wayward, impoverished or sick immigrants came to the attention of authorities. If the federal government were to enforce the terms of its Immigration Act, it required the co-operation of the provincial governments. The Ontario 
government too had a vested interest in joint efforts, for provincial finances were the ones drawn upon to serve the immigrant "failure." This community of interest led to the creation, in 1906, of a provincial bureaucracy of deportation in Ontario to parallel the federal bureaucracy. No department was established, nor any formal bureau. Rather the provincial system, since it dealt primarily with the inmates of hospitals, asylums and prisons, was directed by the Inspector of Prisons and Public Charities. Its reports were made available in the pages of the Annual Reports of the Inspector relating to the Hospitals for the Insane, and were submitted to the legislature and published in the annual Sessional Papers.

S.A. Armstrong was the chief Inspector of Prisons and Public Charities in Ontario from 1906 until 1909. Though his tenure was short, Armstrong held the chief post in the developing provincial deportation bureaucracy during its crucial initial years. Judging by his reports in the Sessional Papers, he assumed the task with alacrity. His enthusiasm far surpassed that of his successors, who deemed it sufficient to simply list the numbers of deportations effected, in each category, during the previous year. ${ }^{19}$ Certain concerns were foremost in Armstrong's reports. He emphasised the financial benefits which would accrue to the province through deportation - even attempting to estimate the existing "burden" of the foreign dependent and delinquent. His concern with the numbers and proportions of "failed" foreigners within Ontario's borders led him to develop copious statistics and charts establishing their disproportionate contribution to the resident populations of the province's asylums, prisons and gaols. ${ }^{20}$ According to Armstrong, the cost of maintaining the inadequate immigrant was one placed unfairly upon the provincial government by a federal inspection system entirely unable to fulfil its obligations, and Armstrong referenced the findings of the prolific superintendent of the Toronto Asylum, Dr. C.K. Clarke, and adopted the latter's lobby for federal medical inspectors who were skilled in assessing mental health problems. In Armstrong's view there was clearly a need for a more restrictive immigration policy since " $[t]$ he foreign born are of a particularly defective type with, in many instances, a pedigree of insanity as their foundation." 21 Moreover, the deportation provisions, though clearly beneficial, were marred by the difficulty of their execution. Considerable problems could be encountered in trying to determine the history of the immigrant for deportation purposes, particularly if the individual did not speak English, was insane or forgetful, or deliberately provided incorrect information to delay the deportation. Such problems called for more careful central record-keeping.

Like Armstrong, R.W. Bruce Smith served as an Inspector of Prisons and Public Charities, but he occupied a position on a lower rung of the hierarchy. His tenure extended from 1904 until 1915 during which time he inspected hospitals, charities, and common gaols. In his yearly reports, Smith frequently endeavoured to warn the public about "the undesirable immigrant class." $22 \mathrm{He}$ 
was convinced that large numbers of undesirable and unsuitable persons were being actively encouraged to emigrate by officials in Europe and that Ontario was being made the "dumping ground" of the "Old World." The fault for this state of affairs lay entirely with the inadequate systems for the federal inspection of immigrants. Quantity not quality seemed to be the goal of the federal government, and it was the hospitals, public charities, and jails of Ontario which were forced to pay the price. So when the Immigration Act was amended to allow deportation, Smith was quick to instruct the province's sheriffs about their responsibility to forward information about immigrants who had committed crimes or become public charges, to permit deportations to be pursued. ${ }^{23}$ Still, Smith complained that the deportation bureaucracy was too complicated and the process took too long, resulting in the release of certain criminals from jail, rather than their deportation, at the expiration of their sentence.

Dr. C.K. Clarke was both the most vehement and the least officially powerful member of the developing provincial deportation bureaucracy. ${ }^{24}$ However, his position as medical superintendent of first the Kingston Asylum (until 1905), then the Toronto Asylum (from 1905 until 1911), and finally the newly developed Toronto General Hospital (from 1911), put him in a position of enormous power with respect to the persons under his care. He also endeavoured to extend his influence, seemingly finding an ally in S.A. Armstrong, writing articles for medical journals and later co-founding and then serving as medical director of the Canadian National Committee for Mental Hygiene (established in 1918). ${ }^{25}$

Clarke differed from his medical superintendent colleagues in the intensity of his concern with the danger posed to the health of Canada by "the defective immigrant." 26 In his view, immigrants contributed disproportionately to the insane and feebleminded populations. "It is all very well to talk about pumping in the population," he wrote, "but surely the streams tapped should not be those reeking with degeneracy, crime and insanity."27 And Clarke believed, like Smith, that "it is undoubtedly the policy of the old world to retain its active and successful workers and to allow the restless, shiftless, and disturbing elements to go to the new world." 28 It was clear to Clarke that the system of federal medical inspection had proven itself inadequate; it imposed an unfair burden on the province by permitting to enter those it should have prohibited, and it had failed to put the enterprise on a sound scientific footing with men trained to detect mental illnesses in positions of authority. Clarke recommended a "preventive medicine," one that would protect the health of future generations from the degenerative effects of defective immigration. ${ }^{29}$

But while Clarke differed from most of his medical colleagues in the intensity of his concern with immigrants, he also parted company from his colleagues among the nascent deportation bureaucracy in his enthusiasm for deportation. Unlike them, Clarke considered deportation to be a necessary 


\section{Left History 7.1}

second line of defence against the defective immigrant and not a sign of the failure of medical inspection. Deportation permitted immigrants, whose deficiencies might pass undetected in the initial medical inspection, to be returned "whence they came" once the latent defect became manifest. Clarke bolstered his argument for the necessity of deportation with medical references and lobbied for the extension of the residency period, during which time immigrants could be legally deported..$^{30}$ Prior to the inclusion of deportation within the Immigration Act, Clarke argued for removal within a two to three year period, citing the American example of a three year residency. ${ }^{31}$ Once the Act had been amended, he lobbied for the residency period to be extended beyond the two year limit. ${ }^{32}$ In 1909, he recommended a residency rule of four years, "as this would enable us to weed out defectives pretty thoroughly, as well as discover those whose former history cannot be learned at the time of landing." 33

The writings of Clarke, Smith and Armstrong do not encompass the whole of the official provincial discussion of "failed" immigrants, but these three were the most prolific commentators prior to the First World War, and they were the most intimately involved both with individual immigrants and with the provincial deportation bureaucracy. ${ }^{34}$ Ian Dowbiggin cautions that it is inaccurate to construe these provincial workers and their federal counterparts as a "unified front" in opposition to immigrants. Relations between federal and provincial officials were often tense, and doctors like C.K. Clarke fostered such antagonisms, while engaging in heated attacks on bureaucrats and the political control of immigration and asylum policy generally. ${ }^{35}$ Nonetheless, the writings of these individuals constitute an official record which suggests that deportation was an entirely calculating and unambiguous procedure. The official, public discussion of "failed" immigrants in Ontario conceived of an individual who, through deviance, disease or disability, came to the attention of public authorities; in such cases, so long as the federal government could be convinced to act, the deportation was understood as automatic - those immigrants who "failed" were to be deported, and mitigating circumstances were not to be considered. In the case files on deportation maintained by the Ontario Inspector of Prisons and Public Charities, however, the situation was less straightforward. Deportations from Ontario were not prosecuted according to clear guidelines, and deportation was not the only possible outcome of immigrant "failure."

The period from 1906 to the First World War is characterised by Roberts as a time of "increasing systematization and formalization of deportation procedures." 36 The fiscal year 1908-9, when the Ontario deportation case files begin, saw the first significant peak in the rate of deportation. This increase, like those which followed it, responded to a period of economic depression, and the official statistics for the year reflected this fact, showing a peak in deportations for the category, "public charge." 37 In Ontario, the turn to a more 
legal and formal approach to deportation, and the intensification of deportation efforts, was supported by an increasingly sophisticated system for compiling case information. As Steven Maynard has pointed out in his analysis of psychiatric case histories of male homosexual conduct in Ontario, S.A. Armstrong, the Ontario Inspector of Prisons and Public Charities, had announced "a new system of case-book or clinical records" for the provincial Asylums in $1906 .^{38}$

The case files maintained by the Ontario Inspector provide a non-public, but still official, perspective on deportation. Their existence reflects the intervention of those with some power into the lives of those with less. ${ }^{39} \mathrm{As}$ Franca Iacovetta and Wendy Mitchinson point out, case files testify to bureaucratic "intrusion and coercion," and the application of "moral and social pressures to conform." 40 The fifty-one case files reviewed in this study do not constitute a random sample, and no statistically valid conclusions can be reached. ${ }^{41}$ Nonetheless, the diversity in the sample is relevant: twenty-four of the cases did not result in deportation, four involved deportations into Ontario, the resolution of two cases was unclear, and twenty-one of the cases involved completed deportations. ${ }^{42}$ The offences committed by the investigated individuals are not readily classifiable. The categories of medical, moral, criminal and financial offences overlap. Individuals were generally impoverished when they were arrested for vagrancy or when they were too sick to work, and moral misdeeds were more visible among the impoverished than among the better-off. ${ }^{43}$

Compiled by bureaucrats with their own, sometimes impenetrable, agendas, the Ontario deportation case files disclose selective narratives rather than transparent truths. The immigrants involved might be stated to have admitted to their crimes, or be willing to return to their country of origin, but other documentation could demonstrate the existence of contrary claims by the immigrants, their families or friends. Problems of interpretation are compounded by the fact that the deportation case files are not uniform in their content. Some contain a wealth of documents, including medical case histories, immigration forms, and official correspondence among various state actors, such as the local Sheriff or Asylum Director, the provincial Inspector, or the federal Superintendent of Immigration; they might contain correspondence from intervenors acting on behalf of the immigrant, whether employers, friends, family members or lawyers; some files even contain correspondence from the immigrants themselves. On the other hand, some case files are sparsely documented. While the lengthy files provide some insight into the range of competing claims and interpretations, and the complicated process of deportation investigation, the brief files all too readily suggest clarity. Even where the files are rich in documentation, Iacovetta and Mitchinson stress, the records cannot be read "as though they represented an unmediated text on a person's life." Instead, they can be used to "illuminate the 


\section{Left History 7.1}

ways in which dominant class, gender, and racial ideologies shaped official discourses and action, and relations between experts and clients." ${ }^{\prime 4}$

\section{DEFINING THE DEPORTABLE}

Barbara Roberts has argued that the deportation system served the administrative imperative to deport. Rather than individual immigrant offences providing the incentive for expulsion, the determination to expel often preceded and inspired the search for an "offence" to justify the deportation. This was particularly so for immigrant radicals. ${ }^{45}$ My case files evidence a similar, though more subtle, process. Deportation investigations might be inspired by an "offence" - such as dependence on public funds, or residence in a jail or asylum - but the decision about deportation then relied upon judgements about the capacity of the investigated persons to become "good citizens." For these judgements to be exercised, administrative flexibility was essential. This flexibility had three key components: first, the use of both legal and extralegal processes; second, an apparatus of de facto probation which permitted the immigrant's worth to be evaluated over a longer period; and finally, the malleability of the diagnosis of "deportability."

In the period captured by these case files, the administrators of the developing deportation system evidenced considerable flexibility in their application (or avoidance) of available laws. Such flexibility ensured that, where expulsion was the preferred outcome, it could be achieved. Roberts has argued that this period of flexibility reflected both the older pattern of ad hoc and extralegal deportations that had existed prior to 1906, and the steady formalisation of the deportation machinery. ${ }^{46}$ Ian Dowbiggin argues that some of this "flexibility" was the result of provincial efforts, and was resisted by federal officials. ${ }^{47}$ The case files suggest that there were occasional "private" deportations co-ordinated and financed by local charities; these deportations paid little attention to the niceties of legal status, but they were often condoned by deportation officials. Moreover, the public authorities would co-ordinate extralegal deportations ("under the Act or otherwise") if they could obtain the permission of the immigrant, and crucially, the consent of family members in Europe who would be prepared to receive and care for the deported immigrant. ${ }^{48}$

Nicholas Reeves, a forty-three year old Englishman, had been committed to the London Asylum as a manic depressive in 1906. After arriving in Canada in 1905 he had worked for the Grand Trunk Railway but grew melancholic, threatened violence and assaulted his wife. Once incarcerated, Reeves, his wife and two children, were considered candidates for deportation. W.D. Scott, the Superintendent of Immigration, noted that Reeves had come to Canada "some time before the present Immigration Act became law," but he hoped still that it would "be possible to send the man ... back to the Old Country." Investigation of Reeves" case took some time; he was "too demented and forgetful to place 
any reliance on his words," so tracing his family was difficult; moreover, he was unwell and at times deemed too sick to travel. The authorities eventually gathered the requisite information: they learned that the man's wife and children had already been "deported" by private subscription. When Reeves was committed, a local collection had been taken up and his "dependants" were returned to their European home. The immigration authorities also had their worst fears confirmed about the mental status of Reeves: his mother was an "imbecile" and the inmate of a workhouse, and his brother had twice been committed to an asylum. Scott wrote that, since he wished "to relieve the London Asylum and public funds of Ontario of further care of [Reeves] .... the Department of the Interior ... [would] bear the cost" to transport Reeves, with an attendant, back to Liverpool. In due course, Reeves was escorted to Montreal and passage was booked. Once on board, however, tragedy struck. Leaping over the guard rail of the ship and wresting himself loose of the attendant who tried to save him, Reeves declared that "he was no good, that it was no use of him going home." Reeves drowned. ${ }^{49}$

A happier case involved a married Englishwoman with four small children. Mrs. Pethers had been abandoned by her husband who had returned to England. Left alone in Canada, she had been committed to the Toronto Jail and then transferred to the asylum while her children were in the care of the Children's Aid Society. Having arrived in 1906 and remained in Canada until 1910 , her case was not covered by the Immigration Act, but she was said to be willing to return and signed her mark, an " $X$," to a letter confirming this consent. Her family were soon in contact with the immigration authorities. The mother wrote that "though a poor woman, there'd be a home for her and her children so long as my husband can work." "If she were to see me," the mother added, "she'd be right again. Please send her and her children home, I would be ever so grateful." The provincial authorities informed their federal counterparts of the situation. "We are anxious to send her home to her parents," the Inspector wrote, "who are likewise anxious to have her." The federal authorities sought the "usual charity rate" for extralegal deportations from the transportation company, assembled a party of deportees returning to England so that Pethers' young children could be supervised, and sent her and her children to her mother. ${ }^{50}$

In cases of completed deportations, whether legal or extra-legal, immigrants were ultimately deemed beyond the pale of citizenship. But many deportation investigations did not lead to expulsion; instead, immigrants might be confirmed as "desirable." In such cases, investigations worked to generate and enforce conformity with certain explicit requirements and implicit norms, often through a system of de facto probation manifested through "suspended deportation."

Probation was generally considered if the deportation process could not be completed smoothly because of the intervention of the immigrant under 


\section{Left History 7.1}

investigation, or of his or her family, employers or the officials most closely involved with the case. The existence of Ontario's informal probation system is apparent in six cases in my sample. In one case, the requirements of the probation were not met, calling down on the family the full force of deportation; in the case which introduced this paper, the profoundly interventionist nature of the probation system is apparent, for the Dorsets were twice investigated and twice granted leave to stay; in four cases, the probationary requirements were satisfied and these immigrants were, in effect, sanctioned in the eyes of the deportation bureaucrats as potential future citizens.

William Murphy was a thirty year old single Irish man charged with two counts of theft and sentenced to a two month term in the Toronto Jail. Since Murphy had arrived in Canada in 1910, he was a clear candidate for deportation, but while under investigation, a letter was sent to the authorities by a friend of the prisoner - this friend was a department head at the Simpson Company of Toronto where the prisoner had worked as a mail clerk prior to his incarceration. The writer pleaded for leniency: it was a first offence and he was sure that the immigrant would "do what's right and lawful if given a chance." In addition, the petitioner promised to do his best to secure Murphy proper employment upon his release. The authorities were sufficiently impressed to grant this request, but Murphy was clearly informed that his status was conditional. If he again came unfavourably to the notice of the department, immediate action would be taken to have him deported. ${ }^{51}$

Another probationary case involved a twenty-three year old married man from Austro-Hungary (or Russian Poland). George Drangova was charged with aggravated assault and sentenced to four months in the Hamilton Jail. Deportation proceedings were begun against him and his wife and the deportation was ordered, but the sheriff intervened requesting that the order be held over the prisoner's head for the balance of two years. The man's offence, the sheriff explained, was a trivial one and it was a first conviction. The sheriff had gradually come to an understanding of the incident, though with difficulty because of the language barrier. Drangova had been collecting wood on the GTR track when the incident occurred. He came upon a pile of wood that, unbeknownst to him, belonged to another gatherer who attacked him with a stick fearing he was a thief. Drangova brandished a piece of wood in self defence, and the antagonist, a woman, then charged him with assault, claiming that he struck her. This story being accepted, the deportation was dropped and the immigrant "given another chance to become a good citizen of Canada." 52

Immigrants tended to come to the attention of the deportation authorities because they became involved with a public institution such as a jail, asylum or through seeking relief. Often then, there was a definable "offence" that the individual had committed which could support the goal of deportation. But the decision to deport tended to use, rather than be driven by, these categories of 
offence. The categories were more functional than prescriptive. This is perhaps most evident in relation to medical diagnoses which could prove remarkably malleable.

Medical practitioners were involved in the deportation process at various sites. They superintended the institutions and supervised the patients where potential deportees were resident; under such circumstances, medical professionals were intimately involved in the deportation investigation, obtaining and providing the requisite information for the Inspector and Superintendent. But even in situations that were not explicitly medical, when cases concerned financial, criminal or moral violations of the implicit social contract, medical practitioners were involved - a doctor's certificate and signature were required on the relevant forms. At times, physicians observed this requirement in a way that did not involve them in the deportation decisionmaking process, stating only that the individual was physically able to withstand a voyage or engage in common labour. ${ }^{53}$ More often, however, the certificate provided a diagnosis that directly addressed the issue of "deportability." Physicians provided a medical diagnosis which justified deportation through reference to the individual's insanity, mental deficiency or particular physical affliction. Yet despite the involvement of physicians in decisions to deport, their medical diagnoses did not have concrete prescriptive value. Diagnoses were often parenthetical, supporting an existing conviction of the immigrant's undesirability, rather than determining that undesirability. In eight cases of those under review medical diagnoses were tested by time and events, and through this testing revealed themselves as conditional and functional.

In 1913, a single Scottish man, thirty five years old, who had been working as a gardener at Exhibition Park in Toronto, became ill, and voluntarily admitted himself to the Toronto Hospital for the Insane. Paul Banting suffered from feelings of persecution and was possibly also suffering the after-effects of influenza from which he had recently recovered. Once in the Asylum, deportation proceedings were begun with special haste since as a voluntary patient he could elect to leave with five days notice. Though Banting gave notice, the deportation order was issued and he was held until it could be effected. His deportation, however, did not proceed smoothly. Once in Montreal, he seems to have impressed the medical staff with his sanity and this prompted a re-investigation of his case. In addition, the office in London, England found no evidence of insanity in Banting's family. With a revised medical diagnosis Banting was released - on probation. He was required to report at intervals to the authorities, and if he demonstrated any signs of further illness, he was to be promptly deported. ${ }^{54}$

Paul Banting was apparently able to intervene in his own defence. Such an intervention required the skills of language and personal presentation which many non-English speaking immigrants did not possess. The case of a forty 


\section{Left History 7.1}

year old Italian man demonstrates how issues of language influenced medical diagnoses. Bruno Gallotti was admitted to the Toronto General Hospital in the summer of 1911. Dr. C.K. Clarke, who brought the case to the attention of the relevant authorities, diagnosed Gallotti as suffering from congenital heart disease and considered his case to be hopeless. "If allowed to remain in Canada," Clarke wrote, "he will be a charity case." Tracing Gallotti's history was made more difficult by his limited English skills. According to Clarke, he was "unable to speak any English and appears to be somewhat more stupid than the ordinary immigrant." The details of Gallotti's case, specifically the date of his arrival, were eventually traced and his deportation was ordered but by then the "hopeless case" had left the hospital - apparently having recovered. ${ }^{55}$

Banting had used his personal skills to prove his sanity, Gallotti was almost deported because of his poor grasp of the English language, but John Gales, a young Irish man who was arrested for vagrancy and sentenced to sixty days hard labour, used a rather different strategy. While Gales' crime had been tramping, the doctor's certificate insisted that the man was mentally "well below the average labourer." He was to be deported as both mentally deficient and a loafer who was perpetually seeking relief. The deportation investigation was initiated, but the officials responsible were unable to trace Gales' history. The jailer concluded that the prisoner suspected the motive behind the persistent questioning and protected himself by providing inadequate and incorrect information. Gales' strategy - if this is what it was - worked. His sentence expired and he was released before he could be deported. The medical diagnosis of mental deficiency, which supported the intention to deport, appears to have been quite wrong. ${ }^{56}$

Taken together, the flexible use of the law, the apparatus of probation, and the malleability of the diagnosis of "deportability" supported administrative flexibility and allowed the deportation investigation to operate as a system for both expulsion and moral regulation. Ultimately, deportation decisions were made on the basis of evaluations of social worth. Such evaluations responded to the efforts of the immigrants themselves, or their allies, to avert expulsion. If people protested, and crucially, if they had the resources to muster a defence, the administrative machinery slowed down. This gave people time to either dupe the system or demonstrate their conformity with expected standards. Such administrative flexibility was capricious; immigrants decidedly did not have the opportunity of a fair hearing. But these delays did permit some immigrants and their allies to serve as partial agents in their own observance of the norms of Canadian society. ${ }^{57}$ Such efforts are especially evident in deportation investigations where social expectations regarding gender norms, the family and sexual morality were operative. 
GENDER, SEXUAL MORALITY AND THE FAMILY

The official record of Ontario's deportation bureaucracy talks of the single "failed" immigrant. But as Franca lacovetta has argued, the immigrant experience "has been largely a matter of families," and this is no less true of the deportation experience..$^{58}$ Indeed, agents of the deportation bureaucracy were, in practice, fully conscious of the importance of families, particularly when they were not in evidence, as in the case of the single, female immigrant. Deportation investigations paid close attention to families and, in the process, reproduced and enforced differential and stratified obligations on family members - obligations defined by gender, class and life cycle.

The operative expectation in cases involving spouses was that of female dependence and male provision. Despite evidence to the contrary, the deportation authorities expected every wife to be a dependent and her husband her sole support. Exceptions to that pattern were not readily acknowledged; the burden of proof rested with the individuals involved and was accepted only where the individual conformed to expectations of moral purity and industry. Married women were therefore in a precarious position. If their husbands deviated from the expected path of the successful immigrant, they were personally liable. The reverse was not true for their husbands. But the situation was not only one of female disadvantage. Some married women clearly wanted to be returned to Europe if their husbands failed to contribute to the family economy. Moreover, the corollary of female responsibility for male deviance was their lesser personal liability for their own deviance. Incapacitated wives, if cared for by their husbands, were not likely to be deported. The same was not generally true for incapacitated husbands. Some invalid wives were therefore constituted as acceptable citizens in the eyes of the immigration authorities entirely through their "dependent" status. "In other words," as Alan Sears has argued, "normal criteria for exclusion could be overlooked where they might interfere with the immigration of the woman and children in a viable family unit as indicated by the circumstances of an adult male." 59

The cases involving spousal responsibility, of which there were twelve in my sample, are of three main types: those in which the husband was the initial target of deportation investigation, those in which the wife was the target, and those in which the "failure" afflicted both partners. In the cases in which the husband was implicated, and therefore no longer in a position to act as a "bread-winner," the wives were, without exception, investigated for deportation as dependants. ${ }^{60}$ In the cases in which the wife was no longer able to fulfil her wifely duties, the husband was never considered a candidate for deportation. He was, however, expected to provide support for his invalid wife, and on the provision of this support hinged her deportation. In the one clear case in which both husband and wife were deemed insane, considerations of mutual responsibility did not apply and both were deported. ${ }^{61} \mathrm{I}$ focus here on two cases where the husband was the initial target of the deportation 
investigation, and where the wives proved not to be as dependent as the authorities had assumed.

In January 1911, a twenty-three year-old Englishman was confined in the Toronto jail for thirty-days after being convicted of theft. A form identifying this individual as potentially deportable (literally, an "undesirable immigrant") was immediately dispatched to the Ontario Inspector of Prisons and Public Charities who began the proceedings for deportation. The young man, William Stevens, had provided his jailers with information about a wife and five stepchildren in Toronto. The Inspector quickly wrote to Mrs. Stevens with news of deportation proceedings; he asked whether she had any means of support apart from her husband and inquired whether she desired to return with him. The first clue that all was not as it appeared was the return of the letter, since the addressee had not been found. Further questioning of William Stevens (who was ordered detained while the investigation proceeded) revealed that Stevens was only recently married; he had met the widow, Mrs. Mary Suffolk, on the boat over from England in 1909; the next year (nine months prior to his arrest) they had been legally married in Toronto and they had then sent for Mrs. Suffolk's five children. Furthermore, Stevens had sailed to Canada under the name of the widow's deceased husband, William Suffolk, "out of compliment to the lady," the Governor of the Toronto Jail suggested. ${ }^{62}$

Notification was sent to a new address for Mrs. Stevens. She responded that she had no desire to return to England, having "better chances here of a living." Moreover, she was "quite able" to support herself and her children since she received money from the Grand Trunk Railway as compensation for the death of her first husband. The Inspector sent her a second letter asking if she had any objections to the deportation of her new husband. She did not.

Meanwhile the authorities were checking the ship's register to determine Stevens' deportability. Having determined that he was, the Superintendent of Immigration in Ottawa, W.D. Scott, then announced that it had been "decided to deport the wife and other dependent members of the family with the prisoner." Scott asked the Ontario Inspector to ascertain which of the children were dependants and to gather "the usual evidence in order that they may be returned to the Old Country." The Ontario Inspector forwarded the request for information to the staff inspector of the Toronto police who wrote back with the details. Mrs. Stevens, he wrote, came to Canada with her first husband, Mr. Gregory Suffolk, about six years ago; Suffolk was killed by a Grand Trunk train in 1908 and thereafter his wife received $\$ 300$ per annum from the GTR. After her husband's death, she had left for England but then returned to Canada with her five children, ages three to twenty-three, three of whom were working steadily. This employment, together with the allowance from the GTR, meant that there was no danger of them becoming public charges, the staff inspector argued. Moreover, the children would, he hoped, "grow up to be good Canadian citizens." By contrast Stevens, Suffolk's second husband, had proven to be an 
"idle, worthless character," and "she would be glad to get rid of him." The staff inspector closed by "respectfully" suggesting that Mary and her children be allowed to remain in Canada. As a consequence of this intervention, their deportation was dropped and only Mary's second husband was returned to England.

The legal position of Mary Suffolk/Stevens was as a dependant of her second husband. Her status as citizen or alien in Canada was determined by her marital status. Since she had married a legally deportable alien, she had become a legally deportable alien, no matter her previous residence (and likely naturalisation) in Canada. ${ }^{63}$ The deportation authorities did not consider that Mrs. Suffolk had a right to remain in Canada, but they granted her a reprieve because of the support available from her adult children and from her first husband. The industry and moral worth of this family encouraged the administrative flexibility to work in the immigrant's favour, just as the "worthlessness" of William Stevens ensured his expulsion, once investigations were complete. Indeed, considerations of moral worth were so important that they could be sufficient to override financial incapacity.

In February of 1913, authorities at the Toronto Hospital for the Insane forwarded information on another "undesirable immigrant" - Peter Gowland. Gowland was a fifty year-old Englishman who had arrived in Canada in 1911; he had worked as a coachman and janitor but was now pronounced "insane." 64 The Ontario Inspector recommended deportation to W.D. Scott in Ottawa and deportation proceedings were begun. His thirty-six year old wife was located, and both were ordered deported. The case might easily have ended here but Scott soon wrote back with news of a delay. A woman of some social status, a Mrs. Fields, had called at Scott's office in Ottawa seeking a deferral of proceedings pending further "representations in this case." Mrs. Fields notified Scott that Mrs. Betty Gowland was "a very capable servant" who, together with her husband, had been in the employ of a physician on Centre Island. Mrs. Gowland was said to be willing to contribute to her husband's maintenance in order to be permitted to remain in the country. Moreover, it was suggested that the husband was "failing fast," and Mrs. Gowland "would very much like it if the case could be watched for a time before being deported." Fields inquired further about the wife's situation: would Betty Gowland, if deported, be permitted to return to Canada in the event of her husband's death?

As a result of this intervention, Scott suggested that the Ontario Inspector withdraw his request and allow Mrs. Gowland to remain. The Inspector was willing to accept these terms, but desired a bond pledging Mrs. Gowland to pay $\$ 2$ per week for her husband's care. When presented with the bill, however, which was retroactive to the date of her husband's admission, Betty proved unable to make payment. She wrote to the Inspector in early April to explain her situation. "Till my husband went away," she wrote, "I was unable to work as he required all the attention I could give him and I regret to say he was 
unable to work for some considerable time. After he was ... [admitted?] my health broke down so that I have only started to earn and even now am not able to do very much." Betty promised to begin payments soon but asked if it was possible to have the rate reduced because her "earnings are not very large and my expenses have been very great." Inexplicably, her wish was granted. The Inspector wrote to her that the bond she had signed would not be put in force; her husband would remain as a free patient and neither would be deported. In responding, Betty Gowland expressed her "sincere thanks for the great kindness shown me. It means so much to me," she added.

The industry and sincerity of this poor working woman may have elicited the Inspector's sympathy. It is also possible that the fact that wives were not expected to provide for their husbands made her inability to do so excusable, thus conditioning the Inspector's response. ${ }^{65}$ It is likely that her suitability for domestic service, and thus her adherence to class-norms of female behaviour, encouraged the interest and advocacy of an upper class woman, and the support of the Ontario Inspector. ${ }^{66}$

Both Mrs. Suffolk and Mrs. Gowland were respectable married women. They had come to the attention of the authorities not for any of their own actions, but simply because of their legally defined dependence, and thus deportability, when their husbands were investigated. Both women were spared expulsion because of their status as moral and industrious women; one husband was also spared deportation through this status. But not all women were so fortunate. Indeed, as Barbara Roberts has argued, women were at particular risk of being accused of moral offences, and such charges were difficult to counter, especially in the case of single women. Women could readily be seen as sexually immoral; if single, unemployed, a vagrant, or leading an "irregular" life, the moniker "prostitute" was readily applied. Even when respectably married, an accusation of sexual immorality existed as a threat for women, while men seemed largely immune to such a charge, irrespective of their actions.

Five cases in my sample involved deportation on moral (specifically, sexual) grounds. All involved women, and only one involved a man. Of the five women, four were termed prostitutes. All of these were young and single, and all, save perhaps one, had no apparent means of subsistence. Two of the four young women were Canadian citizens deported to Ontario by the American immigration authorities. Ontario returned the favour in the case of a single twenty year old American woman in 1908, two years before immorality was made a legally deportable offence. Lisa Ames' case was brought to the attention of the Canadian authorities by a physician in Norwich, Ontario. She had twice been sentenced to jail, and then to the Mercer Reformatory, on charges of vagrancy, larceny and prostitution. Ames had been in the company of a sixteen year old man, both of whom had arrived in Canada in the employ of a minstrel troupe, alternately termed a burlesque show. Ames and her 
companion were described as vagrants. Lisa was also identified as a prostitute and he as a youth who was living on the avails. The certificate from the referring physician stated that "the prisoner in my opinion is an undesirable immigrant owing to her criminal record and she is fit to be deported."

As the investigation proceeded, more forms were filled out and a second doctor's certificate was even more explicit about the sexual threat this young woman posed to the province. "She is presumably healthy enough," the physician wrote, "except that, being a prostitute, she is likely to spread sexual disorder." Once in the Mercer Reformatory, Miss Ames' story began to be more fully developed. The troupe with which she had been travelling had gone out of business in Canada and failed to pay its employees. Because of limited funds, she had been staying with the young man when both were arrested apparently because of the immorality of her living arrangements and their shared unemployment. Her parents in the United States had written her to return and she was, reportedly, eager to do so. The deportation investigation eventually succeeded in establishing her U.S. citizenship and she was to be sent home upon the completion of her sentence. ${ }^{67}$

In the same year that Lisa Ames was deemed deportable, the case of a twenty-three year old English woman, resident in the Salvation Army Rescue Home in Toronto, was brought to the attention of the immigration authorities. Emma Waterford's case file features two entirely different descriptions of her life, and the outcome of the investigation of her case is unclear. Yet the competing interpretations of Waterford's situation provide an especially revealing glimpse into the moral expectations of the deportation authorities. ${ }^{68}$

Emma Waterford was initially recommended for deportation by the Toronto Police Department. She was described as a "common prostitute and was so before she left England"; in addition, she had been a public charge, and a "vagrant." Upon her arrival in Canada, Waterford was said to have immediately "[gone] to work to get acquainted. In consequence several men contracted venereal disease and some of them took it home to their wives. We know," wrote the outraged staff inspector, "three respectable married women thus suffering." Furthermore, Emma was reported to have admitted to having had the disease in England.

The doctor's certificate on the same form contradicted this story somewhat, stating that Waterford denied having had venereal disease. She also denied being a prostitute but had led an "irregular" life since coming to Canada. "She thinks she would prefer returning to the Old country," the physician wrote. Finally, he added his professional diagnosis, stating as though the reverse would be expected under the circumstances, that "the patient gives no evidence of insanity." The investigation proceeded apace; Waterford's deportation was ordered and she was removed to the Immigration Deportation Hospital in Montreal.

Waterford's story did not end here, however. Once in Montreal, a Toronto 


\section{Left History 7.1}

barrister intervened on her behalf and presented a drastically different interpretation of her situation. Emma Waterford, the barrister insisted, was an educated girl who had held a position in a downtown office prior to being placed in the custody of the Salvation Army Rescue Home against her will and without benefit of any legal proceedings. She spoke three or four languages and had friends who were prepared to provide her with a position through which she could earn an honest livelihood. No charges had been laid and any that were brought would be wholly unjustified. Furthermore, the barrister intended to oppose any attempts to deport Waterford. He added that, having met with her, she appeared to be "a girl who is capable of being a good citizen of this Dominion."

In a second correspondence, the barrister bolstered his story with testimonials sent by the headmistresses of the finishing schools Emma had attended as a young lady, and by a gentleman in Italy for whom she had worked as a lady's help. He challenged the designation of prostitute directly, insisting that Waterford had been wrongly accused. But in attempting to vindicate her, the barrister found it necessary to impute sexual immorality to the heretofore respectable married women. He wrote,

It would seem to me that she is being used as a scapegoat so that persons whose wives are making complaint might get from under. ... It is surely within the range of possibilities that overzealous morality officers have overreached themselves and at least in one case have been guilty of causing a grave injustice.

The Ontario Inspector, S. A. Armstrong, was entirely unmoved by the barrister's interpretation. He remained convinced that Emma Waterford was an undesirable immigrant and he forwarded testimonials to the Superintendent in Ottawa, W. D. Scott, which he felt would sufficiently justify the woman's deportation. "I am under the impression," Armstrong wrote, "that some party is desirous of marrying this woman and it is on his behalf that ... [the barrister] took action."

The testimonials to which Armstrong referred are unavailable, and the case file closes with Waterford's situation unresolved. What is clear, however, is that the debate hinged only on which interpretation of Emma Waterford's character was accurate. If she were the sexually immoral caricature who was initially represented - leading decent husbands astray and infecting innocent wives - then she would be deported. But if her advocates could make a sufficiently convincing argument for the reverse situation - that she was an innocent young woman, and other men's wives were to blame - then Waterford's status as a citizen-in-the-making might be preserved.

In Emma Waterford's case, as in most others, men seemed immune to a charge of sexual immorality. It was a man's economic conduct - his breadwinning capacity - rather than his sexual conduct, which informed deportation decision-making. Yet in one case under review, a case which involved adultery 
and desertion, the sexual morality of a male immigrant did come under close observation, and conditioned the decision to deport. Even here, however, the gravity of moral misdeeds weighed rather differently on the man and the woman involved.

In the spring of 1913, Mrs. Alice Coomb and Mr. Alex Winters arrived in Quebec and made their way to Toronto to set up a new life together with their children. That summer, an irate Staff Sergeant from the Toronto Police Force reported these "undesirable immigrants" to the Inspector. "This woman," he wrote, "deserted her husband ... and brought her three children, ages 11, 8 and 5 with her and is living in adultery with ... [Alex Winters] who deserted his wife and came on the same boat with her" and his three children. The Inspector forwarded this information to Scott in Ottawa, suggesting the suitability of these immigrants for deportation. ${ }^{69}$

Soon, the entire family was ordered deported. But the ruling was not immediately executed as Winters - a cement contractor - had several jobs underway which he was granted a month to complete. In the meantime, the couple did not take the threat of deportation lightly. Alice Coomb wrote to the authorities explaining her situation, and Alex Winters travelled to Ottawa to plead his case personally to the Superintendent of Immigration. Winters managed to negotiate a reprieve, offering virtually all concessions save that he and Coomb should be deported: the six children were to be returned to their parents in England; Winters and Coomb were to cease living together, or even to live in the same city; and Winters was to make arrangements with the parties in England to satisfy the charge of desertion. As a further condition of the probation, Winters was to report to the Department offices on occasion. The case seemed settled, but inside two months the entire family was escorted from the country. A month after the reprieve had been granted, Winters was contacted for information about the addresses of himself and Alice Coomb, and the names of their respective employers. Unwisely, it appears in retrospect, Winters responded with information which indicated that they were still residing together. Their continued engagement in sexually immoral behaviour precipitated their expulsion from Canada in December of 1913.

These are the bare facts, but the file also reveals that Alice Coomb wrote to the authorities to offer a full statement concerning her situation. She was an abused wife whose husband,

has several times got hold of me to strangle me and also threatened to shoot me the last few days I lived with him, and my mother had to stay with me for two nights because of his peculiar ways she dare not go home for fear he would do for me as he had threatened to do while these feelings were on him. My life with him for a long time had been a continual worry. I might also add that he has told my mother while I have been here that he will shoot me now if ever he sees me. If you want corroboration of this my brother ... can testify to its accuracy. 


\section{Left History 7.1}

She added, in an obvious attempt to explain his actions as a function of hereditary weakness, that her husband's father had hanged himself several years previously, and his mother had died in an asylum.

Coomb's letter made no impression on the authorities. Instead, the prevailing interpretation of the case was derived from the Superintendent's interview with Alex Winters. Scott stated that Winters "told me a long story about domestic troubles both his own and ... [Alice Coomb's] and he begs not to be sent home to England. He claims that his wife and ... [Mr. Coomb] are no better in their conduct than he and ... [Alice]." He also offered to return the children but stated that Alice Coomb "will not return to her husband, even if sent back to England." Whether or not Winters sought to corroborate Coomb's interpretation of her situation, the official reason accepted for her desertion was her husband's "carrying on" with Winters' wife. As the Chief Constable of the Toronto Police Department put it, both men had "exchanged wives" in England, but Winters got the "worst of the bargain as he's got six children to keep."

The expectations about spousal relations held by the immigration authorities informed their dealings with Alice Coomb and Alex Winters. Though a sexually immoral act was committed by both members of the couple, it affected them both in different ways. Alex Winter's moral offences included adultery and desertion, but these were mitigated by his employment status and his ability to support his estranged wife and children. His offence does not appear to have resulted in his silencing. Winters favourably impressed his interrogators, and his interpretation of events was discussed. Coomb, by contrast, committed a similar offence but was silenced. Without an acknowledged economic role, and because of the moral infraction inherent in desertion and adultery, her testimony concerning abuse was not recognised and appears to have played no role in the deportation decision-making. It is conceivable that, under certain circumstances, the immigration authorities might accept a husband's abuse as justification for his estranged wife's continued residence in Canada. It is impossible to know whether, in this case, Coomb's self-representation as an abused wife was ignored because she was sexually immoral. What is clear, however, is that the deportation authorities relegated women to a position of dependency, and in so doing, structurally minimised their ability to influence deportation decision-making, unless morally above reproach. Failing, as Alice Coomb did, to conform to gendered social expectations about sexual morality, she, together with her lover and their six children, was deported.

\section{CONCLUSION}

As the Ontario case files suggest, deportation decision-making was a complicated process. Individual immigrants, their families, friends and employers could and did intervene in, and attempt to influence, deportation 
decision-making. Sometimes, as for the Dorsets, whose case was introduced at the beginning of this article, they intervened successfully. Diagnoses of "deportability," including medical diagnoses, were often not definitive; Mr. Dorset's status as a "cripple" was, for example, never contested, but nor was it prescriptive. Informal mechanisms within the deportation system were often operable - for the Dorsets, the investigation by the immigration authorities resulted in a de facto probation of their deportation order; in other cases, extralegal, or even private deportations, were informal but very real possibilities. Finally, gendered expectations about family structure and individual behaviour profoundly influenced the outcome of investigations. For the Dorsets, for example, the gendered expectation of the bread-winning capacities of Mr. Dorset prevailed over his and her medical incapacity in the decision to permit them to stay. Indeed, the administrative flexibility of the deportation system made it particularly responsive to normative expectations of immigrant conduct.

Deportation decision-making was a disciplinary process. It was disciplinary in that its power resided in the lessons it taught and in the conformity it generated. But it was also a process which gave many immigrants the space to either demonstrate their ability to conform with normative standards, or more rarely, manipulate the system to their own advantage. The official records of the Ontario deportation bureaucracy, and the actual case files of Ontario deportation practice, do not corroborate each other. While the official records suggest that those administrators most intimately involved with the deportation system were determined to see as many "failed" immigrants as possible deported, the case files suggest they had additional objectives. These objectives concerned normative expectations about the behaviour of good Canadian citizens. Deportation investigations could result in expulsion, but that was not their sole goal. This was an assimilative enterprise designed to recreate immigrant individuals and immigrant families, to have them conform to expectations about propriety, industry, familial relations, gender roles and sexual morality. If the immigrants under investigation proved resistant for whatever reason, even under the threat of deportation, then that sanction could be utilised. Often, however, such drastic measures were not necessary.

\footnotetext{
${ }^{1}$ This family was brought to the attention of the Inspector by local observers. At various points in the file, it is asserted that church organisations, and/or neighbours requested the intervention by the immigration authorities. It is also asserted that Mrs. Dorset was eager to be returned to England. Archives of Ontario, RG 63, Inspector of Asylums, Prisons and Public Charities, Series A-6, Vol. 76, my case \# 23 (All case files are from this series. In accordance with the research agreement I signed with the Archives to gain access to this material, all names have been anonymized and all case file numbers are those I assigned; the volume numbers are, however, original.)
} 


\section{Left History 7.1}

${ }^{2}$ Barbara Roberts, Whence They Came: Deportations from Canada, 1900-1935 (Ottawa 1988), 3. This paper draws heavily, and I hope builds, on Barbara Roberts' seminal analysis.

${ }^{3}$ With a salary of seven dollars a week as an elevator man, Dorset would not be able support his family effectively, the Superintendent believed.

${ }^{4}$ Donald Avery, Dangerous Foreigners: European Immigrant Workers and Labour Radicalism in Canada 1896-1932 (Toronto 1979). See also: Avery, "Canadian Immigration Policy and the 'Foreign' Navvy," CHA Historical Papers (1972); "Continental European Immigrant Workers in Canada 1896 - 1919: From "Stalwart Peasants' to Radical Proletariat," Canadian Review of Sociology and Anthropology 12:1 (1975).

${ }^{5}$ Barbara Roberts, "Doctors and Deports: The Role of the Medical Profession in Canadian Deportation, 1900 - 1920," Canadian Ethnic Studies 18:3 (1986), 32.

${ }^{6}$ Roberts, Whence they Came, 70.

7 The records at the Archives of Ontario are contained in a sub-series which consists of 46 boxes; in these boxes are numerous files each of which contains from 3 to 9 cases. The selection was made impartially: I selected approximately every third box, one file per box, and all cases in that file.

${ }^{8}$ This figure comes from official reports in the Sessional Papers, and could therefore be somewhat inaccurate. Moreover the ratio of investigations to deportations suggested by these numbers is not exact, as some percentage of the deportations were into Ontario (largely from the US). Nonetheless these figures do give some indication of the omnipresence of investigations into the lives of immigrants.

${ }^{9}$ In her book, The Age of Light, Soap and Water, Mariana Valverde recounts a morality tale told in the early 1920 s by the Presbyterian immigration chaplain in Montreal, the Reverend John Chisholm. In this story, a young immigrant woman attempted to avoid her obligation of domestic service (created by pre-payment of passage by her employerto-be), by taking up with a returned soldier. Chisholm accused her of fraud with respect to her employer, and sexual immorality with respect to her potential husband, and, using the threat of deportation, he forced her to give up her relationship and take up domestic work. Valverde terms this process "moral regulation." Mariana Valverde, The Age of Light, Soap and Water: Moral Reform in English Canada, 1885-1925 (Toronto 1991), 124-5. See also: Mariana Valverde, ed., Studies in Moral Regulation (Toronto 1994). On making citizens through immigration practices see: Franca Iacovetta, "Making 'New Canadians': Social Workers, Women and the Reshaping of Immigrant Families," in Franca Iacovetta and Mariana Valverde, eds., Gender Conflicts: New Essays in Women's History (Toronto 1992), 261-303. Vic Satzewich, "Migrant and Immigrant Families in Canada: State Coercion and Legal Control in the Formation of Ethnic Families," Journal of Comparative Family Studies 24:3 (Autumn 1993), 315-338.

10 On the history of legislation see: Roberts, Whence they Came, Chapter 2; Geoffrey Bilson, "Muscles and Health': Health and the Canadian Immigrant," in Charles G Roland, ed., Health, Disease and Medicine: Essays in Canadian History, Proceedings of the First Hannah Conference (Toronto 1984), 398-411.

11 Bilson, "Muscles and Health," 399.

12 Ian Dowbiggin, "'Keeping This Young Country Sane': C.K. Clarke, Immigration Restriction, and Canadian Psychiatry, 1890-1925," Canadian Historical Review 76:4 (December 1995), 600. 
${ }^{13}$ Bilson, "Muscles and Health," 399.

14 The exception to this identification of the individual with his or her malady was the "deaf and dumb, or dumb, blind, or infirm" who could land if support could be provided for by family. Bilson, "Muscles and Health," 400.

15 Roberts, Whence They Came, 12.

16 Freda Hawkins, Critical Years in Immigration: Canada and Australia Compared, Second Edition (Montreal \& Kingston 1989), 3-4.

17 Ian Dowbiggin, Keeping America Sane: Psychiatry and Eugenics in The United States and Canada, 1880-1940 (Ithaca 1997), 134, 136-7; Angus McLaren, Our Own Master Race: Eugenics in Canada, 1885-1945 (Toronto 1990).

${ }^{18}$ Thomas Southworth, "Report of the Director of Colonization," Ontario Legislative Assembly, Sessional Papers, Vol. 38, part 8, (Session 1906), 7. (Hereinafter, SP).

${ }^{19}$ See the reports of Armstrong's successors in the Reports of the Inspectors of Prisons and Public Charities, SP. C.R.W. Postlethwaite held the position from 1909 to 1912, Edwin R. Rogers from 1911 (with Postlethwaite) until at least 1914, when he shared the position with W.W. Dunlop.

20 S. A. Armstrong, "Statistics," SP, Vol. 40, part 8, (Session 1908), xi-xviii; S. A. Armstrong, $S P$, Chart 1-10, Vol. 35, part 8 (Session 1909).

21 Armstrong, SP, (Session 1908), xvii.

22 R.W. Bruce Smith, "The Undesirable Immigrant Class," SP, Vol. 38, part 8 (Session 1906), 18.

${ }^{23}$ R.W. Bruce Smith, "Deportation of Criminals," SP, Vol. 39, part 7, (Session 1907), 14.

24 On Clarke see: Dowbiggin, Keeping America Sane, Chapter 3.

25 Dowbiggin, Keeping America Sane; McLaren, Our Own Master Race, 59.

26 C.K. Clarke, "The Defective Immigrant," The Public Health Journal, 7, 2 (Nov., 1916).

${ }^{27}$ C.K. Clarke, "Defective and Insane Immigration," SP, Vol. 40, part 8 (Session 1908).

${ }^{28}$ C.K. Clarke, "Immigration," The Public Health Journal, 10, 10 (Oct., 1919), 443.

${ }^{29}$ Ibid.

${ }^{30}$ Clarke cited dementia praecox as a condition which, because of its early age of onset, and the ensuing longevity of the dependent patient, together with the difficulty of detecting its symptoms, made it a prime candidate for a form of "delayed" immigration restriction.

${ }^{31}$ C.K. Clarke, "The Importation of Defectives," SP, Vol. 36, part 9, (Session 1904), 60.

32 C.K. Clarke, "Asylum for the Insane, Toronto," SP, Vol. 39, part 7, (Session 1907), 3.

${ }^{33}$ C.K. Clarke, "Immigration of Defectives," SP, Vol. 35, part 8, (Session 1909), 6.

34 Another important lobbyist was Dr. Helen MacMurchy, who made mention of the problem of the immigrant in her writings about infant mortality and the feeble minded. She advocated a careful medical inspection, and warned of the serious danger posed by the feeble-minded immigrant, whose affliction might not be recognised. On MacMurchy see: McLaren, Our Own Master Race, Chapter 3.

${ }^{35} \mathrm{He}$ writes that the experience of C.K. Clarke "belies the popular notion that doctors, politicians, and bureaucrats formed a unified front conspiratorially dedicated to the xenophobic subordination of immigrants." Dowbiggin, Keeping America Sane, 149.

36 Roberts, Whence they Came, 65. Roberts defined three stages in the development of 


\section{Left History 7.1}

the deportation infrastructure: the first, from the 1890 s to 1906 , was the informal period; the second, from 1906 to 1914 with the introduction of legislation, saw the slow formalisation of the system; the third stage, during the War, was characterised by both a drop in the number of deportations, and a "sharp increase in the intensity of deportation work" as investigators sought out alien radicals under the cover of enemy alien hysteria. My study falls into Roberts' second period; see her Chapter 4.

${ }^{37}$ Roberts, Whence they Came, 37, 44, 48.

${ }^{38}$ Steven Maynard, "On the Case of the Case: The Emergence of the Homosexual as a Case History in Early-Twentieth-Century Ontario," in Franca Iacovetta and Wendy Mitchinson, eds., On the Case: Explorations in Social History (Toronto 1998), 69-70.

39 "The (usually middle-class) staff associated with these sources of power ... generally were concerned to resolve conflicts, bring their clients into conformity with dominant social and political norms, and/or punish political, sexual, and other transgressors.": Franca lacovetta and Wendy Mitchinson, "Introduction: Social History and Case Files Research," in Franca Iacovetta and Wendy Mitchinson, eds., On the Case (Toronto 1998), 6.

${ }^{40}$ Ibid., 9.

41 This was a convenience sample of 51 cases. The selection was made impartially: I selected approximately every third box, one file per box, and all cases in that file. This methodology is far from random; moreover, the files are organised in some sort of thematic and chronological order. Consequently, no statistically valid inferences can be drawn from this sample. It would be invalid, for example, to assess proportions of deportations by ethnicity, gender or offences.

42 One of these involved seventy-six Doukhobours deported from northern Ontario to Saskatchewan, at the latter province's expense. Vol. 697, case \#6.

${ }^{43}$ Roberts argues that these categories could be use flexibly to serve the imperative to deport. Roberts, Whence they Came, 34.

44 Ibid., 5, 6.

45 Barbara Roberts, "Shovelling Out the Mutinous:" Political Deportation from Canada Before 1936," Labour/Le Travail 18 (Fall 1986), 77-110.

${ }^{46}$ Roberts, Whence they Came, 65.

${ }^{47}$ Dowbiggin argues that federal officials were more concerned with the threat of legal action, with the priorities of transportation companies (which wished to minimise expense in returning immigrants) and were less ready to draw attention to the failures of the original medical inspections, and less pessimistic about the merits of existing immigration laws than were provincial officials: 148-153.

48 If an immigrant had resided in Canada for longer than the legal residency period first two and later three years - he or she was technically a naturalised citizen of Canada and not deportable. If the authorities obtained the "permission" of the immigrant, Ontario could be relieved of the responsibility to care for these "failed" immigrants even though it had no right to withhold care from naturalised citizens. But though extralegal deportation clearly advantaged Ontario, both the federal and provincial governments co-operated in the task - sometimes with the explicit acknowledgement that the federal government wished to relieve the provincial and municipal governments of further cost. Since the deportation was not within the Act, the steamship companies were not required to pay the costs of return; instead they were obliged to accept charity rates to be paid by both or either level of government. The case files discuss nine cases 
of attempted extra-legal deportation. Of these, five of the investigated immigrants were not, finally, deported. Dowbiggin suggests that these extralegal deportations by Ontario were especially problematic in the eyes of the federal government. There is no evidence of such friction in the case files I reviewed, but such absences are not especially informative: 149.

49 Vol. 694 , case \#2.

50 Vol. 718 , case \#32.

51 Vol. 727 , case \#40.

52 Vol. 727 , case \#38.

${ }^{53}$ See for example, Vol. 727, cases \#38, \#40; Vol. 718, cases \#30, \#31; Vol. 700, case \#9.

54 Vol. 739 , case \#50.

55 Vol. 727, case \#42. A similar case involved an Austrian man, twenty-nine years of age, in Canada for about a year, who broke his leg while working on the Canadian Pacific Railway in the summer of 1908. He was transferred to the Mimico Asylum and diagnosed as of unsound mind. It proved impossible to trace his identity for purposes of deportation under the Act, but Ontario officials sought to deport him nonetheless. In the end, this man recovered and he was released and not deported. The clarification of his mind corresponded directly with his gradual grasp of the English language - a skill which he had not previously possessed. In effect, therefore, the diagnosis of unsound mind - a curious diagnosis in any event since the man had initially been hospitalised simply for a broken leg - was conceivably a diagnosis of the inability to speak English. Vol. 706, case \#24.

56 Vol. 706 , case \#22.

57 Adele Clarke proposes the term "implicated actor" for these partial agents. See: Adele Clarke and Theresa Montini, "The many faces of RU486: Tales of Situated Knowledges and Technological Contestations," Science, Technology and Human Values 18:1 (Winter 1993), 42-78.

58 Franca lacovetta, Such Hardworking People: Italian Immigrants in Postwar Toronto (Montreal \& Kingston 1992), xvii. Franca Iacovetta, "Manly Militants, Cohesive Communities, and Defiant Domestics: Writing About Immigrants in Canadian Historical Scholarship," Labour/Le Travail 36 (Fall 1995), 217-52.

59 Alan Sears, "Immigration Controls as Social Policy: The Case of Canadian Medical Inspection, 1900-1920," Studies in Political Economy 33 (Autumn 1990), 97.

${ }^{60}$ There are six cases in which the husband was targeted. In one, the wife was abandoned, in two he was convicted of a criminal offence, and in three he was incarcerated as insane. All six wives were automatically considered as candidates for deportation, and with or without their permission, the deportation process included them within its purview. Most of these cases were straightforward; the woman's continued residence was dependent upon the resolution of her husband's case. See Vol. 694 , case \#1; Vol. 718, case \#32; Vol. 727, cases \#38, \#41. In two of these cases the man was allowed to stay and therefore so was his wife. In another one, the man was deported and the wife would have been but she had already been "deported" by private subscription. In the final case, the woman was extra-legally deported back to her parents, having been abandoned by her husband who had already removed himself to England.

61 Vol. 694, case \#1. 


\section{Left History 7.1}

62 The details are confusing; the ship's manifest suggested that a party of 4 had sailed to Canada in 1909, one of these was Mrs. Suffolk, and one likely William Stevens (though identified as William Suffolk); perhaps Mrs. Suffolk sent for her three younger children when she had become better established in 1910. Vol. 718, case \#31.

${ }^{63}$ The irrelevance of the woman's personal status is apparent in a similar case in which the Canadian citizenship of the husband of a deportable immigrant woman was sufficient to disallow her deportation even though he could not afford to contribute to her maintenance in an Asylum. See Vol. 736, case \#46. Roberts discusses the legal status of women under immigration legislation, see: Whence they Came, 25.

64 The Doctor's certificate read: "A patient in the Toronto Hospital for the Insane." Vol. 739 , case \#49

${ }^{65}$ In the reverse case, in which the wife was incapacitated and the husband proved unable to provide for her maintenance, the Inspector did not prove so kind. In this case, in 1906, the husband corresponded with the provincial authorities from northern Ontario where he was working. He had placed his wife in the Asylum and was trying to gather the money to provide for her maintenance; it's "Hell to me all right" he wrote. But his inability to provide for her was inexcusable, and no-one intervened on her behalf - she was quickly deported. Vol. 694, case \#4.

${ }^{66}$ Roberts identifies the importance of such class norms for women - the expectation that they be willing to do domestic work: Whence they Came, 56.

${ }^{67}$ Vol. 703 , case \#16.

${ }^{68}$ Vol. 703, case \#17.

${ }^{69}$ Vol. 739 , case \#48. 